\title{
OBSERVING STUDENTS' ATTITUDES TOWARDS TEACHERS' CODE-SWITCHING IN EFL CLASSES. DOES GENDER HAVE ANY IMPACT?
}

\author{
ALI ASGHAR, Rostami ABUSAEedI \& MALAKEH JAFARIAN ${ }^{1}$
}

Bahonar University, Kerman, Iran

\begin{abstract}
Code-switching is a widespread phenomenon used as a communicative resource both in natural and educational settings. This is very common in bilingual and multilingual settings but not in educational ones. There are varying attitudes towards the use of code switching. The present study was to investigate students' attitudes towards teachers' code-switching in EFL classes. Moreover, gender differences in students' attitudes were observed. To this end, a four-section 20-item questionnaire developed by Yao (2011) was distributed to students. They were also supposed to answer the question regarding their gender identity at the top of the questionnaire. The data were tabulated, and frequencies and percentages were conducted by SPSS program. The findings displayed that students totally had positive attitudes towards code-switching used by teachers in EFL classes. However, there were some situations in which they were not interested in it. Furthermore, this study showed that gender does not cause any significant differences in students' attitudes.
\end{abstract}

Key words: Code-switching, attitude, gender, investigation, EFL clases

\section{Introduction}

Among bilinguals, there are various and usual forms of linguistic behaviors such as borrowing on lexical and syntactic levels, language transfer, interference, pidginization, and creolization (Corder, 1981). However, the most normal and immediate form is code switching(Swigart, 1992; Goyvaert \& Zembele, 1992). It is a widespread phenomenon and used as a communicative resource both in natural and educational settings. Code switching is the natural outcome of not only bilingual or multilingual speakers, but also of second language learners who are trying to acquire another language (Gumperz, 1982; Valdes-Fallis, 1977). Therefore, many researchers throughout the world are attracted to this topic to better clarify issues like function of code switching, reasons for code switching, or attitudes towards it. Gumperz (1982) marked out code switching as the use of more than one language in the course of a single conversational episode. Myers-Scotton (2001) asserted that code switching is a phenomenon that appears on a regular basis both inside and outside of educational settings. Code switching is regarded as "a quite normal and widespread form of bilingual interaction" (Muysken, 1995, p. 177). Moreover, in the light of Brown's claim (2006), code switching is as usual as breathing for some people, it comes naturally and without any attention. The reason could be the internalization of societies and expansion of contacts both in and out of our own communities. In spite of that, some studies have shown that code switching is a strategy used by students to bridge understanding gaps caused by their lack of knowledge or proficiency in language classes (e.g. Greggio\& Gil, 2007; Mahadhir\& Then; 2007; Martin, 2005).

In educational settings, there are varying attitudes towards the use of code switching in EFL classes. For example, Cummins and Swain (1986) argued that "progress in the second language is facilitated if only one code is used in the classroom, asserting that the teacher's exclusive use of the target code will counteract the "pull" towards the native code" (p.105). But Schmitt and McCarthy (1997) claimed that "a learner's L1 is one of the most important factors in learning L2 vocabulary" (p.2) or Cook (2001) declared

\footnotetext{
1 Contact address: Department of English, Bahonar University, Kerman, Iran.
} 
that code switching in language classes is common because of the bilingual situations within these contexts.

Almost related to the use of code switching in classes is the issue of gender. Holmes and Meyerhoff (2005) said that "in any identifiable social group, women and men are different. Gender differences are frequently represented as complementarities, that is, whatever men's language is, women's language is not" (p. 452). In language classes, male and female students usually use code switching for different goals. Rahimi and Jafari (2011) declared that "male students switch when they say humorous remarks while their female classmates switch more frequently when they ask and/or gave L1 equivalents" (p.15). So, because gender plays an important role in students' attitudes to their own language use, it may also affect their attitudes towards others' language use and language alternation (code switching).

There have been several studies on code switching in EFL classes. For instance, Moghadam, Abdul Samad, and Shahraki (2010) examined the students' attitudes towards code switching, the positive impact of code switching on understanding the target language, and the negative impact of code switching on students' learning ability. Borlongan, Lim, and Roxas (2012) investigated the attitudes of university students towards the use of Tagalog-English code switching instruction. The results showed that not only do students have positive attitudes towards code switching, but also it fosters learning.

Despite its importance, much less attention has been drawn to the possible role of gender on students' attitudes towards teachers' code switching in EFL classes. To the best knowledge of the researcher, a study done by Rahimi and Jafari (2011) investigated types and functions of code switching as well as gender preferences. But the analysis of the role of gender on attitudes has been lacking. So, this study is going to investigate students' attitudes and the role of gender on attitudes. It tries to answer the following research questions:

1. What are students' attitudes towards teachers' code switching in EFL classes?

2. What is the impact of gender on students' attitudes towards teachers' code switching in EFL classes?

\section{Methodology}

The focus of this study was on students' attitudes towards teachers' code switching in EFL classrooms. The sample was made up of 74 male and female senior English language students who were randomly chosen from all senior English classes in ShahidBahonar University of Kerman. It is worth mentioning that out of 74 students, 27 belonged to male group and 47 were females.

To gather the needed information, an adapted questionnaire was conducted to analyze students' attitudes in EFL classrooms. The questionnaire consists of four sections and twenty items. Section one elicits some information on teachers' persona according to their use of code switching. Section two elicits participants' attitudes to code switching used for subject access. Section three elicits data to recognize if teachers' code switching was used for classroom management and the forth section elicits attitudes towards teachers' code switching for interpersonal relations. There are five choices to each question item using a Likert-type scale and choices are given marks from 5 to 1 . Students were asked to choose one of the five boxes by each statement. Furthermore, the students were asked to answer a question regarding their gender identity at the top of the questionnaire so as to be able to analyze the second research question.

The Cronbach alpha was estimated .893 in the present study which indicates that the reliability of the questionnaire is very high. The data from the questionnaire were tabulated and frequencies and percentages were conducted by SPSS program.

\section{Findings and Discussion}

\subsection{Findings}

Students' attitudes towards teachers' code-switching, according to each question item in the questionnaire, are presented in the table below: 
Table 2.1. Students' Attitudes towards Teachers' Code-switching

\begin{tabular}{|c|c|c|c|c|c|}
\hline QUESTION & $\begin{array}{c}\text { STRONGLY } \\
\text { DISAGREE }\end{array}$ & DISAGREE & NOT SURE & AGREE & $\begin{array}{c}\text { STRONGLY } \\
\text { AGREE }\end{array}$ \\
\hline Q1 & $2.7 \%$ & $17.6 \%$ & $28.4 \%$ & $45.9 \%$ & $5.4 \%$ \\
\hline Q2 & $10.8 \%$ & $39.2 \%$ & $21.6 \%$ & $24.3 \%$ & $4.1 \%$ \\
\hline Q3 & $12.2 \%$ & $39.2 \%$ & $32.4 \%$ & $16.2 \%$ & $0 \%$ \\
\hline Q4 & $10.8 \%$ & $37.8 \%$ & $33.8 \%$ & $17.6 \%$ & $0 \%$ \\
\hline Q5 & $1.4 \%$ & $23.0 \%$ & $48.6 \%$ & $27.0 \%$ & $0 \%$ \\
\hline Q6 & $8.1 \%$ & $37.8 \%$ & $20.3 \%$ & $31.1 \%$ & $2.7 \%$ \\
\hline Q7 & $4.1 \%$ & $21.6 \%$ & $21.6 \%$ & $40.5 \%$ & $12.2 \%$ \\
\hline Q8 & $6.8 \%$ & $14.9 \%$ & $23.0 \%$ & $45.9 \%$ & $9.5 \%$ \\
\hline Q9 & $2.7 \%$ & $23.0 \%$ & $35.1 \%$ & $32.4 \%$ & $6.8 \%$ \\
\hline Q10 & $2.7 \%$ & $16.2 \%$ & $16.2 \%$ & $51.4 \%$ & $13.5 \%$ \\
\hline Q11 & $5.4 \%$ & $18.9 \%$ & $24.3 \%$ & $45.9 \%$ & $5.4 \%$ \\
\hline Q12 & $14.9 \%$ & $24.3 \%$ & $28.4 \%$ & $32.4 \%$ & $0 \%$ \\
\hline Q13 & $9.5 \%$ & $27.0 \%$ & $14.9 \%$ & $45.9 \%$ & $2.7 \%$ \\
\hline Q14 & $9.5 \%$ & $27.0 \%$ & $29.7 \%$ & $31.1 \%$ & $2.7 \%$ \\
\hline Q15 & $9.5 \%$ & $27.0 \%$ & $33.8 \%$ & $25.7 \%$ & $4.1 \%$ \\
\hline Q16 & $14.9 \%$ & $24.3 \%$ & $35.1 \%$ & $23.0 \%$ & $2.7 \%$ \\
\hline Q17 & $6.8 \%$ & $31.1 \%$ & $37.8 \%$ & $18.9 \%$ & $5.4 \%$ \\
\hline Q18 & $1.4 \%$ & $17.6 \%$ & $18.9 \%$ & $50.0 \%$ & $12.2 \%$ \\
\hline Q19 & $8.1 \%$ & $25.7 \%$ & $31.1 \%$ & $29.7 \%$ & $5.4 \%$ \\
\hline Q20 & $8.1 \%$ & 24.35 & $24.3 \%$ & $36.5 \%$ & $6.8 \%$ \\
\hline
\end{tabular}

\subsection{Discussion}

\subsubsection{Students' attitudes to code-switching}

In the following four sections, students' attitudes to each question item will be discussed by detail and their total views about each section will be concluded.

\subsubsection{Attitudes to code-switching in relation to teachers' persona}

The first question involves students' attitudes to the language proficiency of those teachers who switch codes in EFL classes. Table 2.1.indicates that 51.3 percent of the students "agreed" or "strongly agreed" with the opinion that teachers who switch codes are capable of expressing themselves easily and clearly in both languages. 20.3 percent "disagreed" or "strongly disagreed" and about 28.4 percent were not sure about the opinion on this question.

The second question is about students' attitudes towards whether teachers' code-switching will cause any difficulties in understanding what the teacher talks about. Regarding this question, contrary to the previous one, half of the students $(50.0 \%)$ "disagreed" or "strongly disagreed" with the opinion on the question. 21.6 percent were unsure and 28.4 percent agreed with the opinion. It shows that in EFL classes, teachers' switches may cause students misunderstanding to teachers' remarks.

Question 3 elicits students' attitudes on whether teachers' switches will pollute the languages. About 51.4 percent "disagreed" or "strongly disagreed". However, 16.2 percent "agreed" or "strongly agreed" and 32.4 percent were not sure of it. One of the probable reasons for their choices is that they did not know what "language pollution" means. 
Question 4 concerns students' attitudes towards the relationship between teachers' code-switching and their proficiency in languages. Almost half of the sample (48.6\%) "disagreed" with this opinion that teachers who switch codes are deficient in English. 17.6 percent "agreed" and 33.8 percent were not sure. Totally, the results show that students did not consider these teachers as deficient in English.

The fifth question varies from those of the previous one. This question asks about the same opinion on teachers' proficiency who code switches, from the other side. Table 2 reveals that 24.4 percent of students "disagreed", 27.0 percent "agreed" and less than half (48.6\%) were not sure about the statement. One of the possible causes of students' uncertainty may be the closeness of this question meaning to that of question 4.

As a whole, with regard to the results of these five questions, it can be concluded that most of students acknowledged the relationship between code-switching and teachers' persona. Consistent with what Ferguson (2003) asserted, "far from being an indicator of deficiency in the use of one or both languages, switching codes requires high levels of bilingual proficiency" ( $p .45)$

\subsubsection{Attitudes to code-switching in relation to subject access}

This part attempts to analyze students' attitudes towards the role of code-switching on their understanding of subject matter of lessons. In other words, it observes whether code-switching helps students to better learn what the teacher teaches or not. There are lots of studies (Lin, 1996; Martin, 1999; Pennington, 1995; etc.) which claim that code-switching plays a significant role in providing commentary on the meaning of the texts. The following is the explanation of the five questions investigating various aspects of code-switching used for text clarification.

Question 6 asks whether teachers who code switch are able to alternate their language in all kinds of topic or not. Contrary to what has been anticipated, near half of the students $(45.9 \%)$ "disagreed" or "strongly disagreed" with the opinion on this question. Only 33.8 percent of the sample "agreed" or "strongly agreed" and 20.3 percent of them were unsure. Therefore, it can be inferred that teachers change codes to mother tongue to teach certain aspects of language such as grammatical point or new lexical items, not all kinds of topics.

Question 7 investigates students' attitudes on a more detail opinion. It asks if teachers' code-switching use to better explain the grammatical points and lexical items. More than half $(52.7 \%)$ of student "agreed" or "strongly agreed" ; while 25.7 percent "disagreed" or "strongly disagreed" and 21.6 percent were not sure about the opinion on this question. This result is in accordance with both that of question 6 and also with the hypothesis that teachers often change their language to students' native one when teaching grammatical points and new lexical items.

Question 8 believes that teachers prefer to use students' mother tongue so as to illuminate the cultural points in the texts. The result of opinions verifies this assumption. 55.4 percent of the sample either "agreed" or "disagreed" with this point; 21.7 percent "disagreed" or "strongly disagreed" with it and 23.0 percent were not certain about the claim on this question. This is again in accordance with the idea of two previous questions asserting that teachers can code-switch to illustrate some of the points in specific topics.

Attitudes to question 9 are similar to those in question 8. This question declares that teachers sometimes code-switch for eliciting responses to the teachers' questions and also attracting their attentions. Less than 40 percent $(39.2 \%)$ "agreed" or "strongly agreed", 25.7 percent "disagreed" or "strongly disagreed" and more than one-fourth (35.1\%) were not sure.

The last question of this section asks about students' opinions on whether code-switching would help teachers to better clarify the lesson content they teach. 64.9 percent of the sample "agreed" or "strongly agreed" whereas only 8.9 percent "disagreed" or "strongly disagreed" and 16.2 percent were not certain.

Among five questions in this part, the responses to the sixth one were opposite to common expectations but the rest were supported by most of the students. So, it proves that code-switching is regarded as a fruitful strategy in teaching subject matter of lessons. 


\subsubsection{Attitudes to code-switching in relation to classroom management}

Another situation in which code-switching may occur is the management of classroom behavior to discipline students, to attend to latecomers, and to attract students' attention. In another word, it could refer to students' learning management including negotiating task instructions, eliciting students' Reponses, disciplining them, engaging their attention, and also directing them. The following five questions try to survey students' attitudes towards this aspect of teachers' code-switching in EFL classes.

With regard to question 11 which asserts that "teachers who switch codes from English to Farsi can better clarify task instruction". The responses inclined to agreement. More than half of the sample (51.3\%) expressed agreement, 24.3 percent expressed disagreement and 24.3 percent were uncertain about the opinion on the question. So, it is assumed that code-switching could be considered as a useful strategy to better clarify classroom task instructions.

Question 12 states that "teachers who switch codes from English to Farsi can better discipline the students". Considering this, students almost "agreed" with the statement. 32.4 percent of the sample showed "agreement", while 39.2 percent showed "disagreement" and 28.4 percent were not sure. So, students believed that code-switching is not the best way to discipline students in EFL classes.

Question 13 says that "teachers who code-switch from English to Farsi can better engage students' attitudes". Almost half of the sample (48.6\%) "agreed" or "strongly agreed", while 36,5 percent "disagreed" or "strongly disagreed" and 14.9 percent were uncertain. It can be concluded from the responses that code-switching is not regarded as the most appropriate way for engaging students' attention in EFL classes.

Responses to question 14 which asserts that "teachers who switch codes from English to Farsi can better request quiet" exhibit that only 33.8 percent of the sample "agreed" whereas 36.5 percent "disagreed" and 29.7 percent were not sure about this opinion. It can be understood that this opinion was not agreed even by half of the sample. So, code-switching is not considered a good way to request silence from students in EFL classes.

The last statement of this section, question 15, states that "teachers who switch codes from English to Farsi can better direct (call on) students". 29.8 percent of the students "agreed" or "strongly agreed" with it, while 36.5 percent "disagreed" or "strongly disagreed" with it and 33.8 percent were unsure. The results are not in line with Arthur's claim (1994) that code-switching may be used for addressee specification.

The above results about applying code-switching in classroom management depicts that the students did not purely agree or disagree with the statements. Therefore, it can be inferred that totally, codeswitching is not a good strategy used to manage classroom.

\subsubsection{Attitudes to code-switching in relation to interpersonal relations}

As Yao (2011) claims, classroom is not only a place for gathering together and learning new things in different subject matters, but it is also a place which creates various situations for social and affective relations. For this reason, teachers may use students' native language to make close relationships with individual students. In the following, students' attitudes towards teachers' code-switching in relation to interpersonal relations is going to be analyzed.

Regarding question 16 which declares that "teachers who switch codes from English to Farsi can better encourage students", 25.7 percent "agreed" or "strongly agreed", 39.2 percent "disagreed" or "strongly disagreed", 35.1 percent were not sure. This could be understood that students are not interested in being encouraged in their mother tongue in EFL classes or they are not often encouraged by their teachers.

The opinions on question 17 are similar to those of question 16. About 24.3 percent of the students showed agreement, 37.9 percent showed disagreement and 37.8 percent were uncertain. These two questions analyzed identical opinions about how to motivate students' interests in learning English. 
Question 18 states that "teachers who switch codes from Farsi to English or from English to Farsi can better enliven the atmosphere of class (e.g. make a joke for humor) ". More than half of the participant students (62.2\%) expressed agreement, whereas 19.0 percent expressed disagreement and 18.9 percent were not sure about the opinion on the question. It indicates that code-switching is a good strategy to be sometimes used to change the atmosphere of the classrooms.

Question 19 states that "teachers who code-switch from English to Farsi can better comment on the students' responses". 35.1 percent of the sample "agreed" or "strongly agreed", 33.8 percent "disagreed" or "strongly disagreed" and about 31.1 percent were not certain about the opinion on the question. The results illustrate that teachers' use of native language in order to better comment on students' responses is not the best strategy.

To the last question which states that "teachers who switch codes from English to Farsi can better negotiate with students (reduce distance)". 43.3 percent of the participant students showed agreement while 32.4 percent showed disagreement and 24.3 percent were unsure about this opinion. These percentages indicate that not many students agree that teachers' code-switching is the best way to negotiate with students.

From among the above five questions, it can be inferred that students are interested in teachers' language alternation to refresh the atmosphere of classroom. However, they are not tended to teachers' code-switching for encouragement and praise, to comment on their responses, and also to reduce distance.

\subsubsection{Role of gender on students' attitudes to teachers' code-switching in EFL classes}

According to Rahimi and Jafari (2011) who declared that males and females have different reasons for code-switching use in EFL classes, it was also guessed that they would have different attitudes towards teachers' code-switching in classes. In the present study, to assess gender differences in total codeswitching scores, an independent-sample T-test was utilized. The results indicated that there was not a significant difference between males and females regarding total code-switching scores. Therefore, being a male or female student does not have any impact on attitudes towards teachers' code-switching in EFL classes.

\section{Conclusions}

This paper focused on students' attitudes to teachers' code-switching in EFL classrooms in Shahid Bahonar University of Kerman city. The sample included 27 males and 47 female senior English language students. It aimed at finding out their opinions on teachers' use of code-switching in EFL classes as well as analyzing the probable role of gender on attitudes. With regard to students' attitudes, two aspects were discussed: firstly, students' attitudes towards teachers' code-switching were analyzed; secondly, the impact of gender on students' attitudes was investigated. Table 2 shows that most of the students had positive view on the relation between code-switching and proficiency. Regarding section 2 of the questionnaire, they agreed with all statements except question 6 which states the ability of teachers to code-switch in all kinds of topics. However, students did not consider code-switching as a good way to classroom management. Finally, they were interested in teachers' code-switching to enliven the atmosphere of classes but not for encouragement and praise, to comment on their responses, and also to reduce distance. Furthermore, it is inferred from the results that gender has no significant impact on students' attitudes towards code-switching used by teachers in EFL classes.

\section{References}

Arthur, J. (1994). English in Bostwana primary classrooms: functions and constraints. In C. Rubagumya (Ed.). Teaching and researching language in African classrooms (p. 63-78). Clevedon: multilingual matters.

Brown, K. (Ed.) (2006). Encyclopedia of language and linguistics. Oxford: Elsevier. 
Cook, V. (2001). Second language learning and language teaching. London: Arnold.

Corder, S.P. (1981). Error analysis and interlanguage. London: Oxford University Press.

Cummins, J. \& Swain, M. (1986). Bilingualism in education. Harlow: Longman.

Feruson, G. (2003). Classroom code-switching in post-colonial contexts: functions, attitudes and policies. Alla review, 16, 38-51. doi: 10. 1075/aila. 16. 05 fer, http;//dx.doi.org/10.1075/aila.16.05 fer.

Goyvaerts, D.L. \& Zembele, T. (1992). Code-switching in Bukovu. Journal of multilingual and multicultural development, 13, 17-82.

Greggio, S. \& Gil, G. (2007). Teachers' and learners' use of code-switching in English as a foreign language classroom: a qualitative study. Linguagem \& Ensino, 10(2), 371-393.

Gumperz, J.J. (1982). Discourse strategies. London: Cambridge University Press.

Holmes, J. \& Meyerhoff, M. (Ed.) (2003). The handbook of language and gender. Oxford: Blackwell Publishing Ltd.

Lin, A. (1996). Bilingualism or linguistic segregation? Symbolic domination, resistance and code-switching in Hong Kong schools. Linguistic and education, 8, 9-89.

Mahadhir, M. \& Then, C.O. (2007). Code-switching in English language classrooms in Kuching secondary schools. Sarawak museum journal, special issue, No. 7 on social sciences and humanities, LXIV(85), 197-219.

Martin, P. (1992). Bilingual unpacking of monolingual texts in two primary classrooms in Brunei Darussalam. Language and education, 13(1), 38-58.

Martin, P. (2005). "Safe" language practices in two rural schools in Malaysia: tensions between policy and practice. In M. Y. Lin \& P. W. Martin (Ed.). Decolonization, globalization. (pp. 74-97). Cleveland: multilingual matters.

Muysken, P. (1995). Code-switching and grammatical theory. In L, Milroy \& P. Muysken (Ed.) One speaker, two languages. Cross-disciplinary perspectives on code-switching (pp. 177-198). London, Cambridge University Press.

Pennington, M. (1995). Pattern and variation in use of two languages in in the Hong Kong secondary English class. RELC Journal, 80-105.

Rahimi, A. \& Jafari, Z. (2011). Iranian students' attitudes towards the facilitative and debilitative role of code-switching; types \& moments of code-switching at EFL classroom. The Buckingham journal of language and linguistics, 4, 15-28.

Schmitt, N. \& McCarthy, M. (Ed.) (1997). Vocabulary: description, acquisition, and pedagogy. London: Cambridge University Press.

Swigart, L. (1992). Two codes or one? The inside view and the description of code-switching. Dakar journal of development, 13, 83-102.

Valdes-Fallis, G. (1977). Code-switching among bilingual Mexican-American women:towards an understanding of sex-related language alternation. International journal of sociology of language, 7 , $65-72$

Yao, M. (2011). On attitudes to teachers' code-switching in EFL classes. World journal of English language, 1, 19-26.

Received: 03/03/2016

Accepted: 20/05/2016 